УДК 94(571.150)+39(470.13)

ББК 63.3(2Рос-4Алт)+63.521(=664)

\title{
Экспедиция Л.Н. Жеребцова в Алтайский край в 1969 г. в контексте изучения этноареальных групп народов коми
}

\author{
Н.П. Миронова, С.А. Симакова \\ ФГБУН ФИЦ «Коми научный центр Уральского отделения \\ Российской академии наук» (Сыктывкар, Россия)
}

\section{The L.N. Zherebtsov's Expedition in the Altai Region in 1969 in the Context of the Study of the Ethno-areal Groups of the Komi People}

\author{
N.P. Mironova, S.A. Simakova \\ Federal State Budgetary Institution of Science Federal Research Centre \\ "Komi Science Center of the Ural Branch of the Russian Academy of Sciences" \\ (Syktyvkar, Russia)
}

\begin{abstract}
Представлены исследования этноареальной группы алтайских коми на основе научной и научно-организационной документации отдела этнографии и археологии Коми филиала АН СССР за 1960-1980-е гг., отложившейся в Научном архиве Коми научного центра Уральского отделения РАН. Летом 1969 г. этнографическая группа Сибирского фольклорно-этнографического отряда под руководством Л.Н. Жеребцова проводила исследования в Алтайском крае. Это была единственная экспедиция этнографов Коми филиала АН СССР, в которой были рассмотрены вопросы сохранения языка, фольклора, особенностей материальной культуры и самосознания различных поколений жителей сел Зыряновка, Новозыряново, потомков переселенцев из Коми края в середине XVIII - начале XX в. Отчеты экспедиции 1969 г. содержат богатый материал опросов населения сел Алтайского края, позволяют дать оценку содержания исторической памяти представителей различных поколений потомков переселенцев из Коми края, их этнокультурных ориентаций в конце 1960-х гг., показать множественность форм этнической идентичности и формирование региональной сибирской идентичности в этноареальной группе алтайских коми.

Ключевые слова: этноареальные группы, алтайские коми, миграционные процессы, межэтническое взаимодействие, этническое самосознание, региональная идентичность, Коми филиал АН СССР, Л.Н. Жеребцов.
\end{abstract}

The study of the ethno-areal group of the Altai Komi on the basis of scientific and organizational documentation of the 1960-1980-s of the Department of Ethnography and Archeology of the Komi Branch of the USSR Academy of Sciences is presented in the article. In the summer of 1969 the ethnographic group of the Siberian folklore and ethnographic group under the leadership of L.N. Zherebtsov conducted researches in the Altai Region. It was the only complex expedition of the Komi scientists where the questions of preservation of language, folklore, features of material culture and self-awareness of different generations of the inhabitants of Zyryanovka, Novozyryanovo villages, descendants of immigrants from the Komi Region at the end of $18^{\text {th }}-$ the beginning of the $20^{\text {th }}$ centuries were considered. These studies make a significant contribution to solving the problem of ethnogenesis and ethnic history of the Komi people. The materials of the expedition of 1969 contain material of surveys of the population of the villages of the Altai Region. This information helps to assess the content of the historical memory of the representatives of different generations of immigrants from the Komi Region, their ethnic and cultural orientations in the late 1960's. It shows the multiplicity of forms of ethnic identity and the formation of regional (Siberian) identity in the ethnoareal group of the Altai Komi.

Key words: ethno-areal groups, the Altai Komi, migration processes, interethnic interaction, ethnic self-awareness, regional identity, the Komi Branch of the USSR Academy of Sciences, L.N. Zherebtsov.

DOI 10.14258/izvasu(2019)2-12 
За последнюю четверть века роль этнологической науки в нашей стране значительно возросла, что связано с резким ростом значения этнического фактора в обществе и необходимостью его всестороннего изучения. Этнологическая проблематика тесно сопряжена с вопросами геополитики, государственности, национальной, региональной, этнической форм идентичности, историко-культурными доминантами общества. Изменение общественно-политической ситуации со второй половины 1980-х гг. сопровождалось всесторонней критикой советского «тоталитарного наследия» в отечественной этнологии, которая в своих радикальных проявлениях отчасти переходила в отрицание вековых традиций отечественной науки [1]. В данном контексте особенно актуально становится обращение к истории региональных этнографических исследований и документальному научному наследию советских ученых-этнографов. Возможно новое прочтение и переоценка с позиций современных научно-исследовательских задач экспедиционных данных прошлых лет. Так, например, обращение к теме этноареальных групп коми в истории региональных этнографических исследований имеет важное значение для понимания ассимиляционных и интеграционных процессов у коми в местах переселения, этнической истории народов коми. В то же время обращение к советскому научному наследию актуально для современных этнологических исследований региональной и этнической идентичности народов России.

История этнографического изучения народов коми связана с историей и становлением академической науки на Севере России в целом. Целенаправленная работа по изучению народов Севера нашей страны началась в 1917 г. с создания Комиссии по изучению племенного состава пограничных областей России при Академии наук под председательством академика С.Ф. Ольденбурга. Первоначальной задачей Комиссии было выяснение границ расселения различных племен в Литве, Польше, Галиции, Буковине, а затем - в пограничной части Малой Азии, Азербайджане и Северной Персии. После Февральской революции Комиссия по изучению племенного состава пограничных областей России была преобразована в Комиссию по изучению племенного состава населения России (КИПС). КИПС наметила две основные практические задачи: 1) составление этнических карт с объяснительными записками; 2) написание очерков о народах, проживающих в России. Важное научное и практическое значение имела деятельность КИПС в области этнического картографирования народов Средней Азии, Урало-Поволжья, Сибири и Дальнего Востока [2]. В 1925 г., в связи с предстоящей переписью населения СССР, в КИПС была образована Подкомиссия по подготовке к всеобщей переписи. Она начала заниматься проблемами проведения демографической, сельскохозяйственной, промысловой переписей, очень подробно был разработан вопрос об учете племенного состава населения и составлен список народностей СССР [3]. Комиссия имела большое значение для институционализации этнологических исследований в СССР, в 1930 г. на ее базе создан институт по изучению народов СССР (ИПИН), который в 1933 г. вошел в состав института антропологии, археологии и этнографии АН СССР [4].

Коми переселенческие группы не были специальным объектом исследования Комиссии, но в ее научных отчетах содержится отдельный фактический материал о них [5, с. 7].

Существенный скачок в развитии постоянных этнографических исследований на территории Республики Коми стал возможен с организацией в 1944 г. стационарного академического учреждения в регионе - Базы АН СССР в Коми АССР (с 1949 г. Коми филиал АН СССР, с 1988 г. - Коми научный центр Уральского отделения АН СССР (РАН)) [6; 7]. Этнографические исследования в Коми филиале АН СССР развивались в рамках работы сектора языка, письменности, литературы и истории (с 1953 г. отдел языка, литературы и истории). В 1950-е гг. территория Коми АССР в этнографическом плане практически не была изучена, поэтому первостепенной задачей для первых коми-этнографов стал сбор полевого материала по вопросам материальной и духовной культуры народов коми, этнографическому районированию и этнической истории народов коми [8; 9]. В 1958 г. отдел языка, литературы и истории Коми филиала АН СССР разделили на отдел языка и литературы и отдел истории, этнографии и археологии. В 1961 г. отдел истории, этнографии и археологии был разделен на отдел истории и отдел этнографии и археологии, что позволило увеличить численность научных работников, расширить тематику исследований $[10$, с. 8]. С середины 1960-х гг. в рамках исследований историко-культурных взаимоотношений коми с соседними народами этнографами Коми филиала АН СССР под руководством Л.Н. Жеребцова началось изучение этноареальных групп коми [5; 11]. Научное наследие и вклад Л.Н. Жеребцова в становление коми региональной

*Жеребцов Любомир Николаевич (1925-1991), ученый-этнограф, основоположник коми региональной этнографической школы, канд. ист. наук (1952). С 1952 по 1990 г. работал в Коми НЦ УрО АН СССР, в 1971-1988 гг. руководил сектором этнографии. Научные интересы охватывали традиционную материальную и духовную культуру коми, этнографическое районирование, этническую историю, вопросы исторического расселения коми, историко-культурного взаимодействия коми с соседними народами. 
этнографической школы не раз вызывали интерес исследователей [8-10].

Целью данного исследования является анализ научной и научно-организационной документации отдела этнографии и археологии Коми филиала АН СССР за 1960-1980-е гг., в которых показано значение экспедиции Л.Н. Жеребцова в Алтайский край в 1969 г. для изучения этноареальной группы алтайских коми этнографами Коми филиала АН СССР в рамках большой темы по межэтническому взаимодействию коми с соседними народами. Рассмотренный комплекс документов включает планы научно-исследовательских работ [12], промежуточные и итоговые научные отчеты [13-17], фотодокументы по материалам экспедиции [18].

В конце 1960-х гг. научные сотрудники отдела этнографии и археологии Коми филиала АН СССР в рамках темы «История мировой культуры. История культуры народов СССР» продолжали работу по изучению изменений культуры и быта народов коми и взаимосвязей коми с другими народами в Коми АССР; по выявлению роли различных этнических компонентов в развитии его культуры. Руководителем темы по разделу «Этнокультурные связи народа коми» был старший научный сотрудник Л.Н. Жеребцов [12]. Летом 1969 г. группа Сибирского фольклорно-этнографического отряда в составе пяти человек: начальник - Л.Н. Жеребцов, лаборанты - Г.П. Белорукова, Г.И. Цивунина, художники - И.М. Паршуков, А.Ф. Булышева, проводила исследования в Сорокинском районе Алтайского края, где в конце XIX в. проживали зыряне.

Наиболее ранние сведения об участии зырян в освоении Сибири датированы XV в. [19, с. 61; 20 , с. $116 ; 21$, с. 61]. Первые упоминания о коми переселенцах можно найти в периодических изданиях Архангельска, Вологды, Тобольска последней четверти XIX в. Сведения о коми переселенцах содержат работы, написанные в конце XIX - начале XX в. путешественниками, чиновниками, сотрудниками служб статистики, священниками [5, с. 7]. Нехватка плодородных земель, неурожаи были основными причинами миграций населения северных территорий Российского государства с начала XVII в. В Алтайском крае коми стали селиться с XVIII в. в качестве рабочих КолываноВоскресенских заводов горнозаводчика Акинфия Демидова [13, л. 20].

Сбор полевых и архивных материалов о коми переселенцах участники экспедиции осуществляли в Алтайском краевом архиве, Томском и Новосибирском областных архивах, сельсоветах сел Зыряновка и Новозыряновка Сорокинского района Алтайского края, в этих же селах проводился опрос местного населения, который включал сведения о происхождении переселенцев, записи се- мейных преданий о переселении, занятиях, хозяйственном укладе и быте предков. В целом рабочая программа экспедиции включала обширный перечень исследовательских задач - от анализа состояния материальной и духовной культуры, а также содержания исторической памяти различных поколений потомков коми переселенцев в Алтайский край.

Научный отчет Сибирского этнографического отряда, составленный по материалам экспедиции 1969 г., содержит подробное описание истории переселения, места и образа жизни коми переселенцев и их потомков, их трудовой деятельности, культуры, взаимоотношений с местным населением.

Л.Н. Жеребцов в ходе поисковой работы экспедиции в архивах Алтайского края и Томска выявил многочисленные списки заводских приписных, которые содержат информацию о переселенцах: имена и фамилии, специальности, члены семьи, место, откуда они переселились, их возраст. В списках указаны территории, с которых шло переселение, в том числе большинство волостей Усть-Сысольского и Яренского уездов; указано множество коми фамилий: Гутов, Тарабукин, Нехорошев, Суров, Мезенцев, Момотов, Турунтаев, Выметянин, Паршуков, Кынев, Пырсиков, Кокчегов, Бараксанов, Вымятников, Гилев, Бусов и др.

Также в Алтайском краевом архиве Л.Н. Жеребцовым были выявлены докладные записки о побегах рабочих, объявлений о розыске беглых заводских рабочих конца XVIII - середины XIX в. Несмотря на тяжелые условия работы на заводах, переселенцы из Коми края продолжали прибывать на Алтай до начала ХХ в. [13, л. 21].

В отчете экспедиции приведены сведения за 1969 г. о численности, национальном составе, образовании жителей сел Зыряновка и Новозыряново; выписки из Похозяйственных книг 1940-1942 гг. Новозыряновского сельсовета Сорокинского района Алтайского края с перечислением фамилий из числа местных жителей.

Вначале участники экспедиции побывали в с. Новозыряново ${ }^{* *}$ и выяснили, что в 1969 г. здесь проживали Утевы, Койгородовы, Баяндины, Баталовы, Климовы, Шмаковы, Куимовы, Инюшевы, Каркавины, Гусельниковы и др., которые являлись вероятными потомками коми-пермяков - переселенцев из верхне-язьвинских сельсоветов.

Особый интерес в материалах экспедиции представляют интервью и беседы с потомками переселенцев, записи коми песен и частушек, исполненных местными жителями. В записях экспедиционных интервью с жителями с. Новозыряново прослеживает-

${ }^{*}$ Село Новозыряново основано в 1827 г., находится в северо-восточной части Алтайского края, на правом берегу реки Татарка (приток реки Чумыш), на расстоянии примерно 4 км к северу от города Заринска. 
ся четкая сибирская региональная идентичность, отделение себя от остальной России: «мы сибирские, а они российские».

Возникая первоначально естественным образом как географическое пространственное понятие, в дальнейшем региональная идентичность нередко обретает новые формы выражения, которые опираются на устоявшуюся мифологическую и на развивающуюся историческую традиции, на что указывают современные исследователи сибирской региональной идентичности [22, с. 41-44]. Через апелляции к историческому сознанию, сопричастность к некоторому локальному сообществу, человек переносит на себя или свою социальную микрогруппу прошлые и настоящие достижения региона, в котором проходит его жизнь [23, с. 93-100]. Чувство непрерывности памяти у субъекта, непрерывность и постоянство самосознания обращено к прошлому жизненному опыту человека, что особенно ясно прослеживается в свидетельствах устной истории и воспоминаниях (рис. 1).
Участники экспедиции в ходе работы с похозяйственными книгами Новозыряновского сельсовета проанализировали пофамильный состав потомков переселенцев из Коми края, их национальную принадлежность. Исследователи из группы Л.Н. Жеребцова отметили, что многие зыряне в 1930-1940-х гг. записывали себя "русскими», так как возникали сложности при оформлении официальных документов. Смена этнической идентичности с коми на русскую во многом связана с официальной идеологией и пропагандой советского государства, в которой русский народ провозглашался «великим», «первым среди равных», «старшим братом в советской семье народов», что особенно усилилось после Великой Отечественной войны $[24$, с. 25]. Этническому нивелированию также способствовало официальное провозглашение концепта «советский народ».

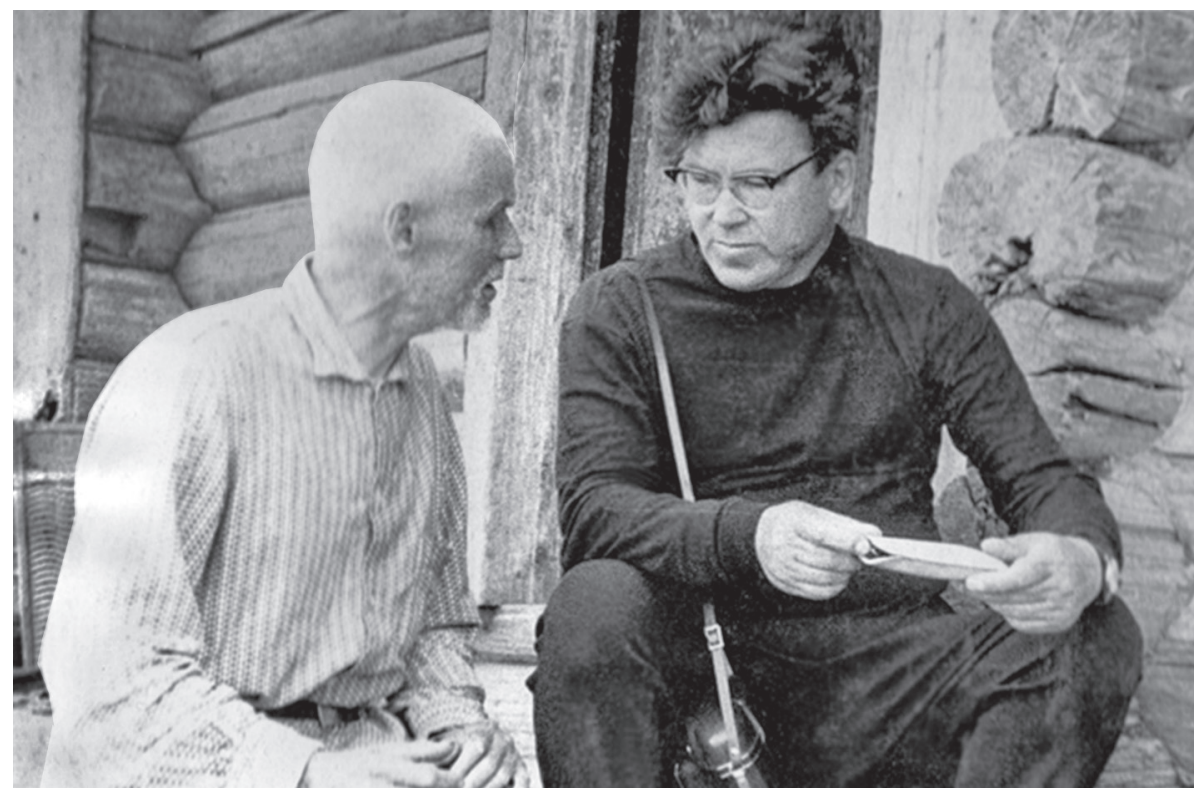

Рис. 1. Начальник отряда Л.Н. Жеребцов (справа) беседует с жителем с. Зыряновка, 1969 г. (Научный архив Коми НЦ УрО РАН. Ф. 1. Оп. 13. Д. 195. Л. 33)

По рекомендации сотрудников краеведческого музея Алтайского края экспедиция также посетила с. Зыряновка ${ }^{* *}$ Сорокинского района, где селились коми переселенцы. В Зыряновке участники экспедиции собирали сведения по материальной и духовной культуре, традиционным занятиям и языковым ориентациям потомков коми переселенцев, записывали устные воспоминания жителей, семейные истории жителей (см. рис. 2).

*** Село было основано около 1803 г., большая группа зырян из Вологодской губернии приехала в Зыряновку около 1870 г.
В экспедиционных записях семейных историй также получили отражение ассимиляционные процессы среди коми населения Алтайского края, их языковые ориентации.

Участники экспедиции 1969 г. отмечали, что на улицах с. Зыряновки звучала коми речь, язык местных жителей был очень чистый. Но в то же время забылось много слов, менее необходимых в повседневном быту, заменили их русскими, как правило, с неправильным ударением, сохранялся характерный коми акцент $[17$, л. 188]. 
Важным итогом работы экспедиции 1969 г. был анализ ассимиляционных процессов в этноареальной группе алтайских коми в исторической перспективе. В итогах работы экспедиции показано, что поскольку первопоселенцы прибыли сюда довольно большой этнической группой, поселились компактно, то вплоть до 1930-х гг. сохранялись устойчивая этническая общность, браки в своей среде и т.д. В ходе процесса коллективизации и совместного труда на производстве произошло сближение коми переселенцев с русскими, мордвой и другими соседями. Получило развитие межнациональное общение, происходит этническое смешение, усиление процесса ассимиляции, утраты черт традиционной культуры предков.

Также работа экспедиции показала, что материальная культура и быт алтайских коми к концу 1960-х гг. почти полностью утратили прежнюю национальную специфику. От многих своих культурно-бытовых традиций, навыков и привычек, предметов домашнего обихода переселенцам пришлось отказаться в новых условиях. Основные заимствования были сделаны из русской культуры. Например, берестяные пестери вышли из обихода, а сам термин оставался для обозначения плетеного короба на телеге. Произошли изменения и в домашнем хозяйстве, например, коми стали держать гусей, уток и свиней. По своим постройкам села утратили сходство с северной деревней. Исчезли крупные постройки, объединявшие под одной крышей жилой дом и двор. Как и в других местах Южной Сибири, в с. Зыряновка построены небольшие и невысокие дома под шатровой крышей, в плане пятистенные или чаще крестовики с небольшой пристройкой для сеней. Хозяйственные постройки здесь стоят отдельно от дома на усадьбе (см. рис. 3). Из предметов традиционной одежды у жителей Зыряновки дольше всего сохранились орнаментированные изделия. Встречались старинные узорные пояса, которые очень берегли, по-прежнему вязали рукавички и чулки, но узоры уже не были яркими.

В результатах работы отряда отмечены отдельные заимствования в русской культуре из культуры коми (передача узоров на вязаных шерстяных изделиях). Показана устойчивость духовной культуры, в особенности фольклора и языка. В ходе работы экспедиции в результате интервьюирования представителей различных поколений среди жителей обследованных сел из национально-несмешанных и национально-смешанных семей, выяснилось, что три поколения переселенцев владели коми языком, пользовались им в семье и в общении друг с другом. Четвертое поколение уже не владело коми языком. Отмечалось преобладание русского языка в разнонациональных семьях. Никаких контактов потомки коми переселенцев с Коми АССР не имели. Изменилось национальное самосознание: молодое поколение уже не формально, а действительно сознавало себя русским [15, л. 53-54, 59].

Таким образом, результаты экспедиции 1969 г. в Алтайский край позволили значительно расширить знания по этнической истории народов коми, показать особенности трансформации этнической идентичности потомков коми переселенцев. Так, исследования этноареальной группы алтайских коми Л.Н. Жеребцова стали частью большой темы

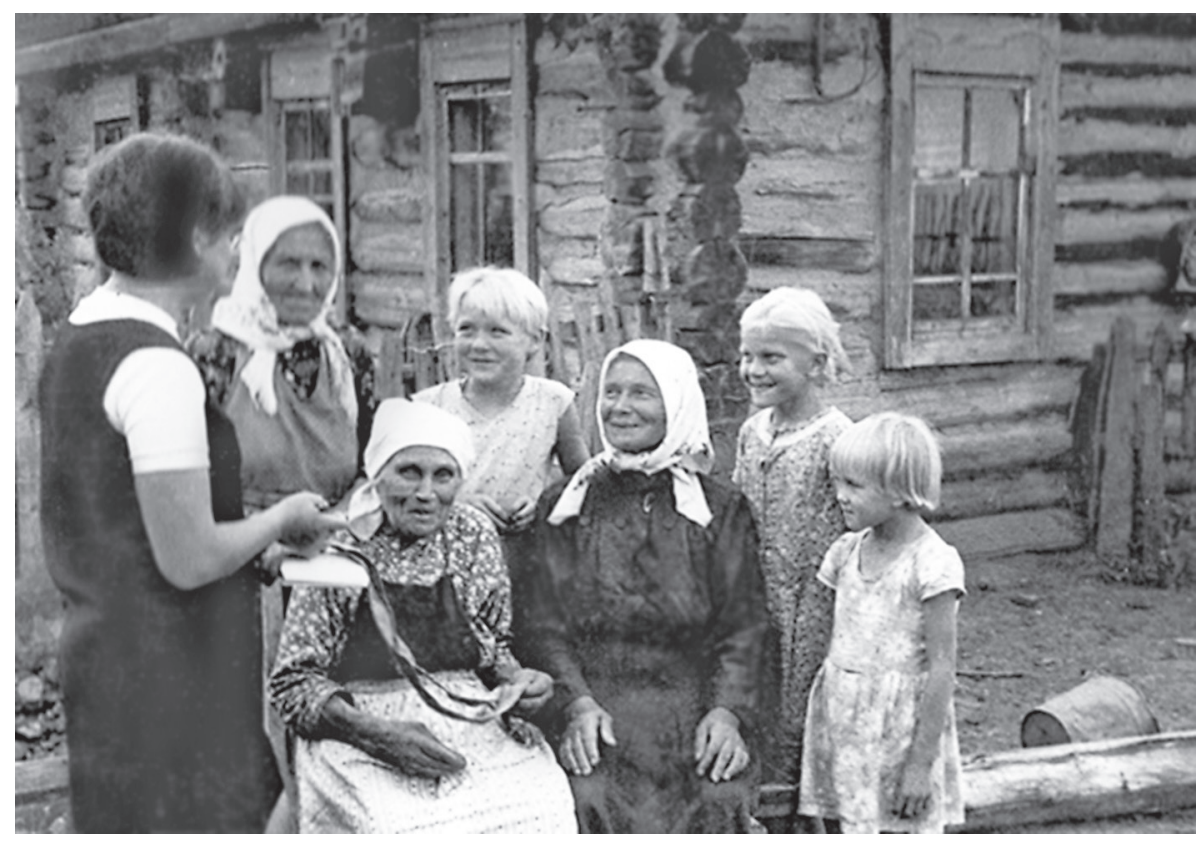

Рис. 2. Член экспедиционного отряда Г.И. Цивунина беседует с жителями с. Зыряновка, 1969 г. (Научный архив Коми НЦ УрО РАН. Ф. 1. Оп. 13. Д. 195. Л. 26) 


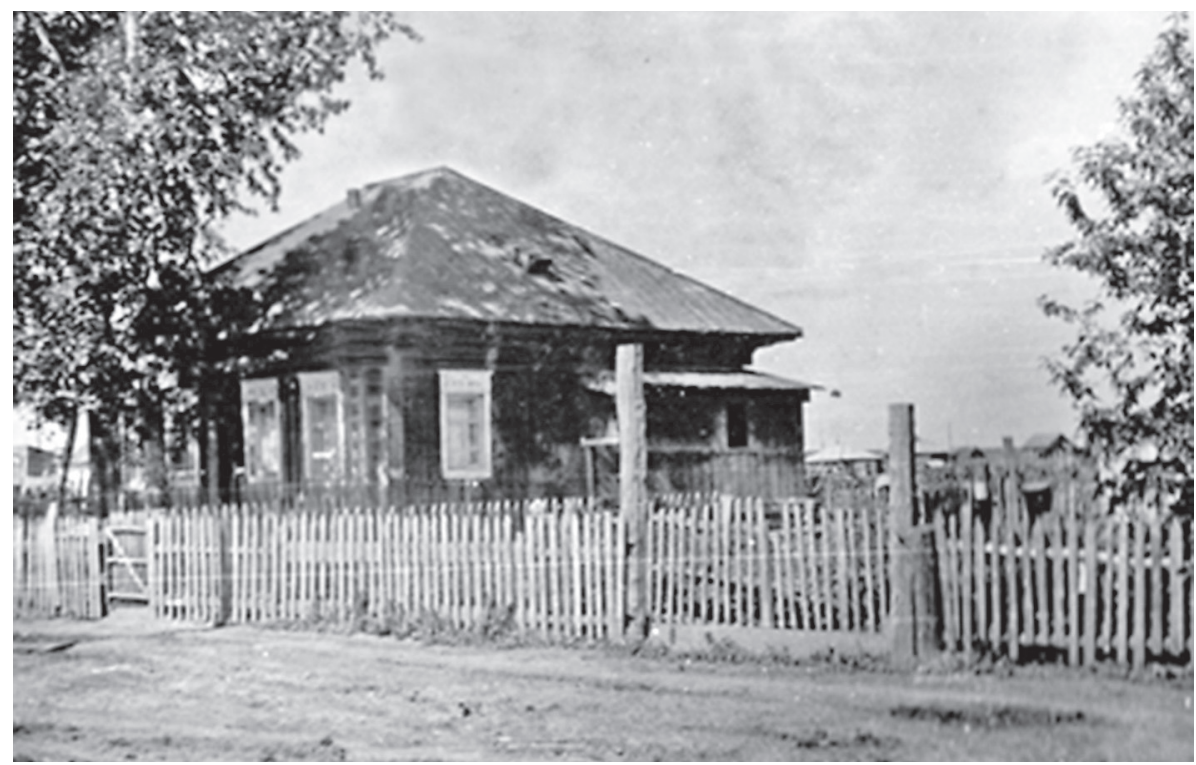

Рис. 3. Характерный тип жилища - дом, украшенный резными наличниками. Село Зыряновка, 1969 г. (Научный архив Коми НЦ УрО РАН. Ф. 1. Оп. 13. Д. 195. Л. 22)

по этнической истории, межэтническому взаимодействию коми с соседними народами и включают сведения по трансформации материальной культуры, изменениям в этническом самосознании, языковым практикам рассматриваемой этноареальной группы. Это была единственная экспедиция коми исследователей по изучению этноареальной группы алтайских коми и во многом личная заслуга Любомира Николаевича Жеребцова как ученого и автора рабочей программы исследования. Результаты работы экспедиции стали частью его большого труда по историко-культурному взаимоотношению коми с соседними народами [11]. Полученные в ходе экс- педиции данные внесли существенный вклад в изучение вопросов этнической истории народов коми. Для современных исследований историко-культурных ориентаций народов России особую ценность представляют записи воспоминаний и свидетельства устной истории представителей различных поколений в отчетных материалах экспедиции, которые демонстрируют сущность исторической памяти, этнической и региональной идентичности и не теряют своей актуальности при анализе самых общих проблем передачи исторической памяти и этнической идентичности в целом.

\section{Библиографический список}

1. Чешко С.В. От советской этнографии к российской этнологии // Этнологическое обозрение. 2002. № 2.

2. Материал для обсуждения на Международном симпозиуме «Востоковедение в России и странах СНГ на рубеже веков. Проблемы и перспективы». Казань, 2-5 июля 2007 г. [Электронный ресурc]. URL: http://ansya.ru/health/ vostokovedenie-v-komissii-po-izucheniyu-plemennogosostava-nas/main.html.

3. Список народностей Союза Советских Социалистических Республик / под ред. И.И. Зарубина. Л., 1927. (АН СССР. Комиссия по изучению племенного состава населения СССР и сопредельных стран. Труды комиссии. Вып. 13).

4. История ИЭА РАН // Официальный сайт ИЭА PAH [Электронный ресурс]. URL: http://iea-ras.ru/index. php?go $=$ Content\&id $=13$.
5. Конаков Н.Д., Котов О.В. Этноареальные группы коми: формирование и современное этнокультурное состояние. М., 1991.

6. Конаков Н.Д., Шабаев Ю.П. История этнографического изучения народов коми // Очерки по истории изучения этнографии коми. Сыктывкар, 2007.

7. Документальная история Коми научного центра УрО РАН. Коми филиал АН СССР в 1965-1987 гг. / сост. Л.П. Рощевская, А.А. Бровина, А.В. Самарин, Э.Г. Чупрова, Т.П. Филиппова, Н.П. Миронова. Сыктывкар, 2011.

8. Жеребцов Л.Н. Дороги этнографа. Сыктывкар, 2005.

9. Савельева Э.А. Любомир Николаевич Жеребцов // Очерки по истории изучения этнографии коми. Сыктывкар, 2007. 
10. Ученые Института языка, литературы и истории Коми научного центра УрО РАН : биографический справочник. Сыктывкар, 2000.

11. Жеребцов Л.Н. Историко-культурные взаимоотношения коми с соседними народами. М., 1982.

12. План научно-исследовательских работ Коми филиала АН СССР на 1969 г. // Научный архив Коми НЦ УрО РАН. Ф. 1. ОП. 1. Д. 958.

13. Жеребцов Л.Н. Научный отчет Сибирского этнографического отряда об итогах 1969 г. // Научный архив Коми НЦ УрО РАН. Ф. 1. Оп. 13. Д. 194.

14. Жеребцов Л.Н. Отчет отдела этнографии и археологии Коми филиала АН СССР о выполнении плана научно-исследовательских работ за 1969 г. // Научный архив Коми НЦ УрО РАН. Ф. 1. Оп. 1. Д. 964.

15. Жеребцов Л.Н. Отчет (заключительный) о научноисследовательской работе по теме «Этнокультурные связи народа коми» за 1966-1970 гг. 1971 г. // Научный архив Коми НЦ УрО РАН. Ф. 5. Оп. 2. Д. 6.

16. Жеребцов Л.Н. Историко-культурные связи народа коми : итоговый отчет за 1971-1975 гг. // Научный архив Коми НЦ УрО РАН. Ф. 5. ОП. 2. Д. 142.

17. Жеребцов Л.Н. Заключительный отчет по теме «Историко-культурные взаимоотношения коми с сосед- ними народами» 1980 г. // Научный архив Коми НЦ УрО РАН. Ф. 5. Оп. 2. Д. 264.

18. Альбом 1 (Приложение к отчету 1969 г. Сибирского этнографического отряда) // Научный архив Коми НЦ УрО РАН. Ф. 1. Оп. 13. Д. 195.

19. Миллер Г.Ф. История Сибири. Т. 1. 2-е изд., доп. M., 1999.

20. Народы Сибири / под ред. М. Г. Левина, Л. П. Потапова, М. ; Л., 1956.

21. История Коми с древнейших времен до современности. Т. 1. 2-е изд., испр. и доп. Сыктывкар, 2011.

22. Дутчак Е.Е., Львова Э.Л., Нам И.В. Сибирская региональная идентичность - фактор конфликта или ресурс формирования общероссийской идентичности? // Известия Иркутского гос. ун-та. Серия: История. 2012. № 2 (3). Ч. 1.

23. Бочаров А.В. Сибирская региональная идентичность в контексте исторического сознания (по результатам контент-анализа томских СМИ) // Вестник РУДН. Серия: Социология. 2011. № 4.

24. Вдовин А.И. Подлинная история русских. ХХ век. M., 2010. 